\title{
The Effect of Melinjo (Gnetum gnemon L.) Leaves and Melinjo Peel Extracts on Induced-Hyperuricemia Male Rats Model
}

\author{
Nia K Sari*, Andreanus A Soemardji**, Irda Fidrianny** \\ *Indonesian School of Pharmacy \\ Jl. Soekarno- Hatta no.354 (Parakan Resik), Bandung 40266, Jawa Barat Indonesia \\ **School of Pharmacy - Bandung Institute of Technology \\ Jl. Ganesha no. 10 Bandung, Jawa Barat, Indonesia \\ Email: remy.nia@gmail.com
}

\begin{abstract}
Hyperuricemia is a condition which blood uric acid levels increase, in men are greater than $7 \mathrm{mg} / \mathrm{dL}$ and in women over $6 \mathrm{mg} / \mathrm{dL}$. In Indonesia the prevalence of hyperuricemia was $32 \%$ in people under 34 years and increases every year. This study aims to assess the effect of melinjo leaves and peel extracts to reduce uric acid levels on hyperuricemia male rats model. Induction was performed by giving high purine diet, crude melinjo seed $4.5 \mathrm{~g} / \mathrm{kg}$ bodyweight. Ethanol extracts of melinjo leaves and peel were administered in 3 doses. The study showed ethanol leaves extract of melinjo (Gnetum gnemon L.) $36 \mathrm{mg} / \mathrm{kg}$ bodyweight decreased uric acid levels up to $61.04 \%$, while ethanol peel extract of melinjo $13 \mathrm{mg} / \mathrm{kg}$ bodyweight decreased uric acid levels up to $31.25 \%$. We concluded ethanol extracts of melinjo leaves and peel have the effect to decrease uric acid blood levels in hyperuricemia rats.
\end{abstract}

Keywords : Gnetum gnemon L., seed, leaves, peel, antihyperuricemia 


\title{
Kajian Pengaruh Ekstrak Daun dan Kulit Buah Melinjo pada Tikus Jantan Hiperurisemia Biji Melinjo (Gnetum Gnemon L.)
}

\author{
Nia K Sari*, Andreanus A Soemardji**, Irda Fidrianny** \\ *Sekolah Tinggi Farmasi Indonesia \\ Jl. Soekarno- Hatta no.354 (Parakan Resik), Bandung 40266, Jawa Barat Indonesia \\ **Sekolah Farmasi - Institut Teknologi Bandung \\ Jl. Ganesha no. 10 Bandung, Jawa Barat, Indonesia \\ Email:remy.nia@gmail.com
}

\begin{abstract}
Abstrak
Hiperurisemia adalah keadaan dimana terjadi peningkatan kadar asam urat darah, pada pria lebih dari 7,0 mg/dL dan pada wanita lebih dari $6,0 \mathrm{mg} / \mathrm{dL}$. Di Indonesia tercatat prevalensi terjadinya hiperurisemia adalah sebesar $32 \%$ pada masyarakat usia di bawah 34 tahun dan terus meningkat setiap tahunnya. Penelitian ini bertujuan untuk mengkaji pengaruh ekstrak daun dan kulit buah melinjo (Gnetum gnemon L.) pada tikus jantan hiperurisemia. Induksi dilakukan dengan makanan tinggi purin yaitu suspensi simplisia biji melinjo dengan dosis $4,5 \mathrm{~g} / \mathrm{kg}$ bb selama 9 hari. Ekstrak etanol daun dan kulit buah melinjo diberikan masing-masing dalam 3 dosis. Induksi dengan simplisia biji melinjo $4,5 \mathrm{~g} / \mathrm{kg}$ bb selama 9 hari dapat meningkatkan kadar asam urat. Penelitian ini mendapatkan bahwa ekstrak daun melinjo $36 \mathrm{mg} / \mathrm{kg}$ bb mampu menekan kadar asam urat hingga 61,04\%, sedangkan ekstrak kulit buah melinjo $13 \mathrm{mg} / \mathrm{kg}$ bb mampu menekan kadar asam urat hingga 31,25\%. Dari penelitian ini disimpulkan bahwa ekstrak etanol daun dan kulit buah melinjo dapat menurunkan kadar asam urat.
\end{abstract}

Kata Kunci : Gnetum gnemon, L., daun, kulit buah, antihiperurisemia 
Research Article

\section{Introduction}

The prevalence of hyperuricemia has increased worldwide. In Indonesia, the prevalence of hyperuricemia is $32 \%$ in people under 34 years and increase every year. ${ }^{1}$ One factor that influences the high prevalence of hyperuricemia is consumption of "emping", a kind of snack made from melinjo seeds, and consumption of melinjo seeds in "sayur asem", a vegetable soup favored by the Indonesian population. ${ }^{2}$

It is important to find natural compounds which can reduce uric acid levels with high effectiveness and guaranteed security. ${ }^{3,4}$ Leaves and peel of melinjo are known to contain flavonoids, which can reduce uric acid levels by inhibiting the action of xanthine oxidase enzyme. The flavonoid is a potential compound with antihyperuricemic activity. ${ }^{5}$

This study aimed to assess the effect of melinjo leaves and peel extracts to reduce uric acid levels on hyperuricemia male rats model.

\section{Methods}

\section{Plant Material}

Seeds, leaves, and peel of Gnetum gnemon L. were taken from the botanical garden of Monoko, Cikampek, West Java, Indonesia. The specimens were identified in Herbarium Bandungense, Sekolah Ilmu dan Teknologi Hayati, Institut Teknologi Bandung, West Java, Indonesia.

\section{Preparation of sample}

Melinjos were peeled to separate the peels and seeds. Melinjo seeds were dried and mashed for hyperuricemia induction. Leaves and peels of melinjo were extracted by reflux method with a concentration of $96 \%$ ethanol. Melinjo leaves and peel extract were concentrated with the rotary evaporator and then evaporated over the waterbath.
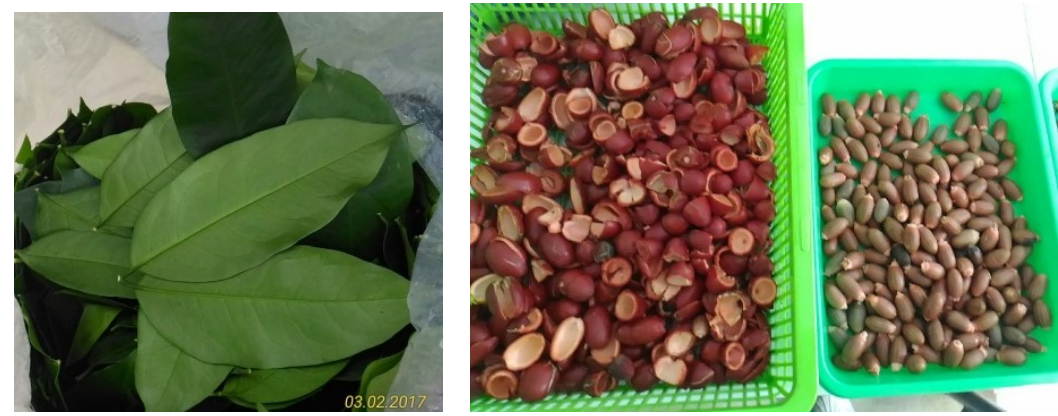

Figure 1 Leaves, peel, and seed of Melinjo 


\section{Preparation of animal test}

\section{Antihyperuricemic assay}

This study used male Wistar Rats, weighted $180-200$ g, aged 6-8 weeks. ${ }^{6}$ The animals were procured from animal house, Biofarma Laboratory, Cisarua, Lembang, Indonesia. Animals were kept in light and dark cycle every 12 hours. All animals were fed on a standard balanced diet and provided with water ad libitum. All animal experiments were conducted under institutional ethical guidelines for a week.

The assay was performed using ten groups of male Wistar rats and each group consists of five rats. Animals were fasted for 10 hours before day one measurement. In the next morning the animals were measured for the pre-induction uric acid level using a spectrophotometer. All groups except the Group I (non-hyperuricemia) were given a simplicia of melinjo seed $4.5 \mathrm{~g}$ / $\mathrm{kg}$ bodyweight orally to induced hyperuricemia. Within 1 hour after induction, all groups were treated according to the treatment regimen. Group I (non-hyperuricemia) was given Na CMC 0.5\% suspension orally; Group II (positive control) was inducted without treatment; Group III was given allopurinol $10 \mathrm{mg} / \mathrm{kg}$ bodyweight; Group IV was given probenecid $100 \mathrm{mg} / \mathrm{kg}$ bodyweight after 9 days of induction; Group V, VI, VII were given ethanol extract of melinjo leaves at dose 18,36, and $72 \mathrm{mg} / \mathrm{kg}$ bodyweight; Group VIII, IX, X were given ethanol extract of melinjo peel at dose 13,26, and $52 \mathrm{mg} / \mathrm{kg}$ body weight.

Assessment of uric acid levels by serum measurement was carried out on day 4, 7, 10, 14, and 18. Induction was stopped after 9 days of induction, and treatment was stopped on day 18. Blood was collected from tail vein, and was centrifuged at $10.000 \mathrm{rpm}$ for 10 minutes. The uric acid level was measured using kit reagent by spectrophotometer (Microlab $300 \circledR$ ).

\section{Statistical analysis}

Analysis between treatment groups was done using one-way analysis of variance (ANOVA) and independent t-test analysis using SPSS software version 21.0. Values with $\mathrm{p}$ $<0.05$ indicate significant differences. 
Research Article

\section{Results}

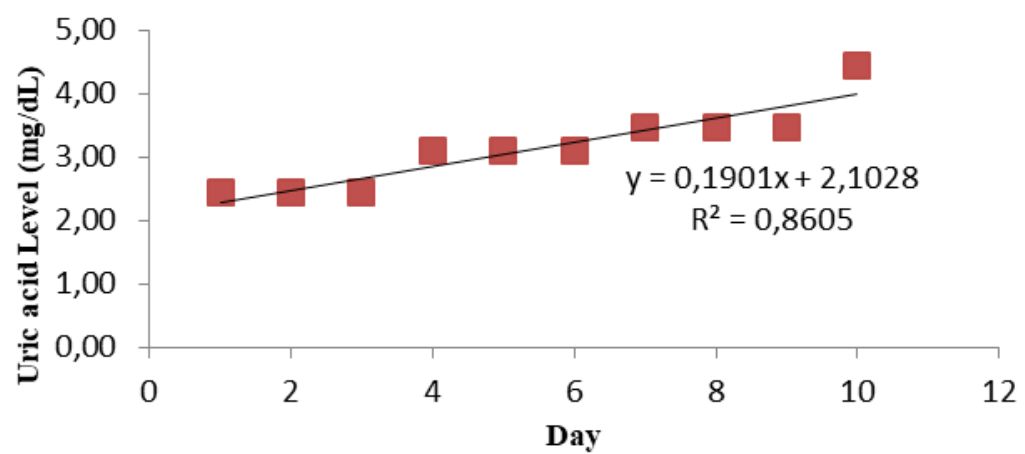

Figure 2 The regression curve of uric acid levels in test control group as measured by spectrophotometer uv-vis

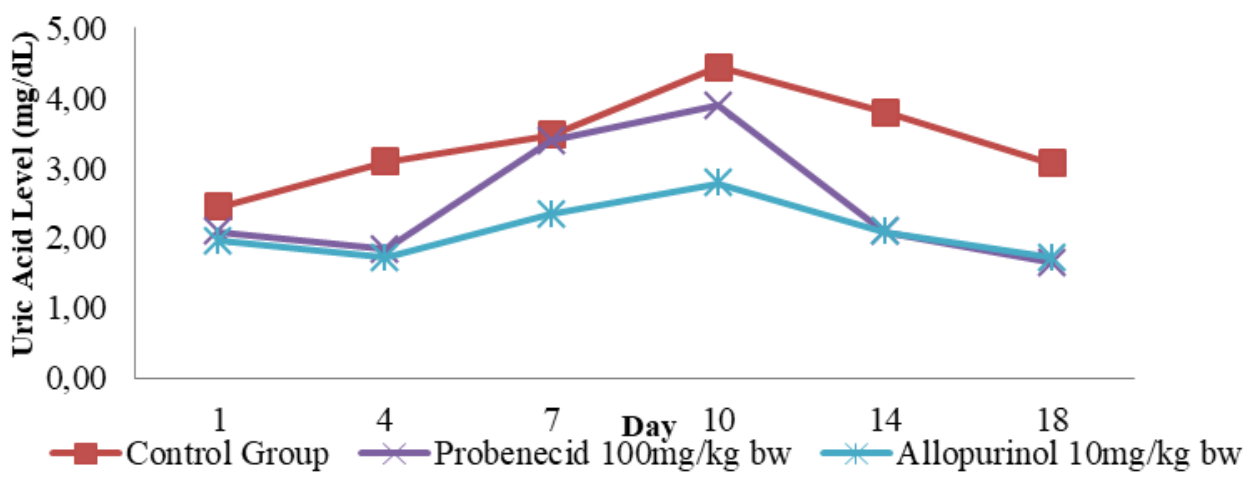

Figure 3 Graph of uric acid levels by treatment of comparative drug therapy as measured by a spectrophotometer uv-vis

Suspension of simplicia melinjo seeds was able to significantly increase uric acid levels in male rats blood by $81.2 \%$ as measured by spectrophotometer on day 10 , compared to the normal group $(\mathrm{p}<0.05)$. The allopurinol and probenecid groups were both significantly different from positive control group ( $\mathrm{p}<0.05$ ), on day 4 for allopurinol and day 13 for probenecid. 
Research Article

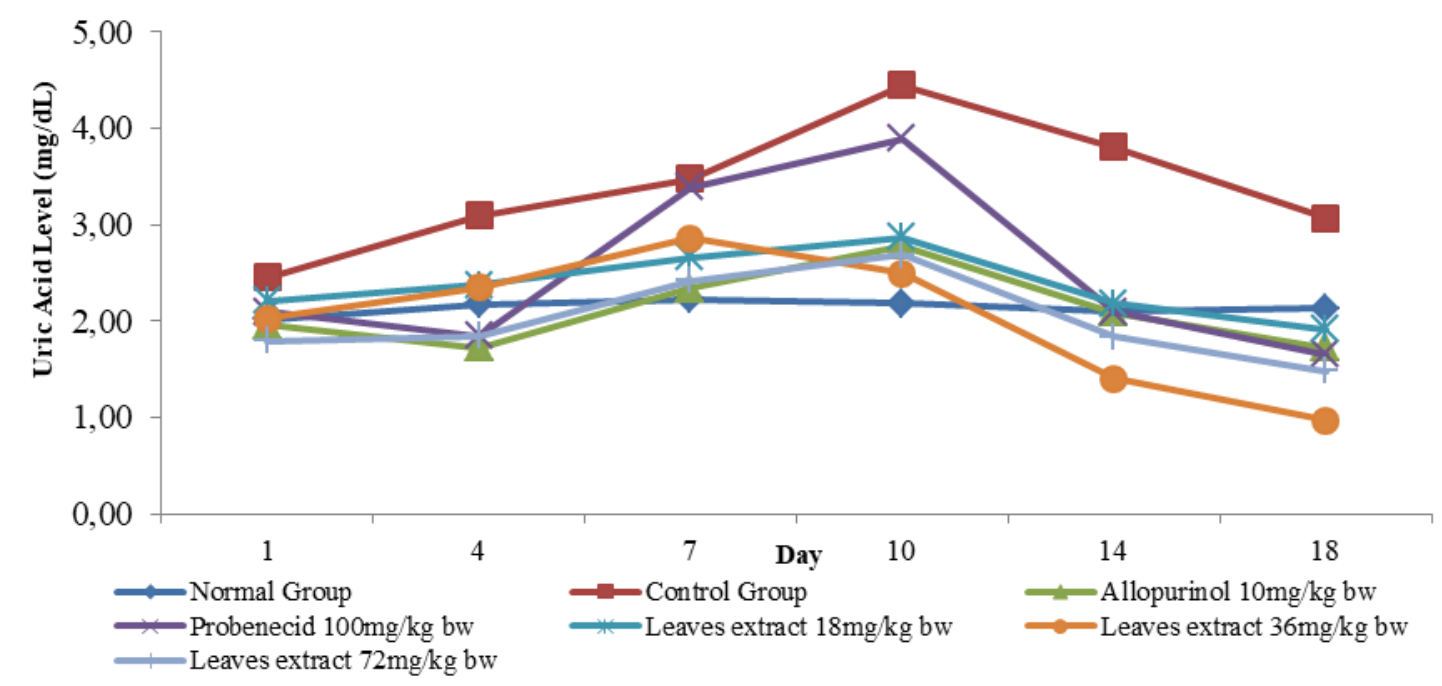

Figure 4 Graph of uric acid level with treatment of melinjo leaves extract measured by a spectrophotometer uv-vis

The dose of melinjo leaf extract $18 \mathrm{mg} / \mathrm{kg}$ bodyweight can significantly reduce uric acid levels $(p<0.05)$ against the positive control group starting on day 4 . The level of uric acid in hyperuricemia group of rats given dose of melinjo leaf extract of $36 \mathrm{mg} / \mathrm{kg}$ bodyweight and $72 \mathrm{mg} / \mathrm{kg}$ bw were significantly reduced $(\mathrm{p}<0.05)$ compared to positive control group starting day 6, whereas allopurinol group did not show any significant difference. Thus melinjo leaves extract of $18 \mathrm{mg}, 36 \mathrm{mg}$, and $72 \mathrm{mg} / \mathrm{kg}$ bodyweight can reduce uric acid level in the same potency as allopurinol. On day 11 melinjo leaves extract of $36 \mathrm{mg} / \mathrm{kg}$ bodyweight also showed a significant difference to probenecid $(\mathrm{p}<0.05)$.

Melinjo leaves extract decreased uric acid level after reaching maximum increase (100\% hyperuricemia) until last day of treatment, at dose $18 \mathrm{mg} / \mathrm{kg}$ bodyweight equal to $33,45 \%$, at dose $36 \mathrm{mg} / \mathrm{kg}$ bodyweight equal to $61,04 \%$, and at a dose of $72 \mathrm{mg} / \mathrm{kb}$ bodyweight of $44.7 \%$. Dose $36 \mathrm{mg} / \mathrm{kg}$ bodyweight leaves extract of melinjo is the most effective dose to decreased uric acid level. 


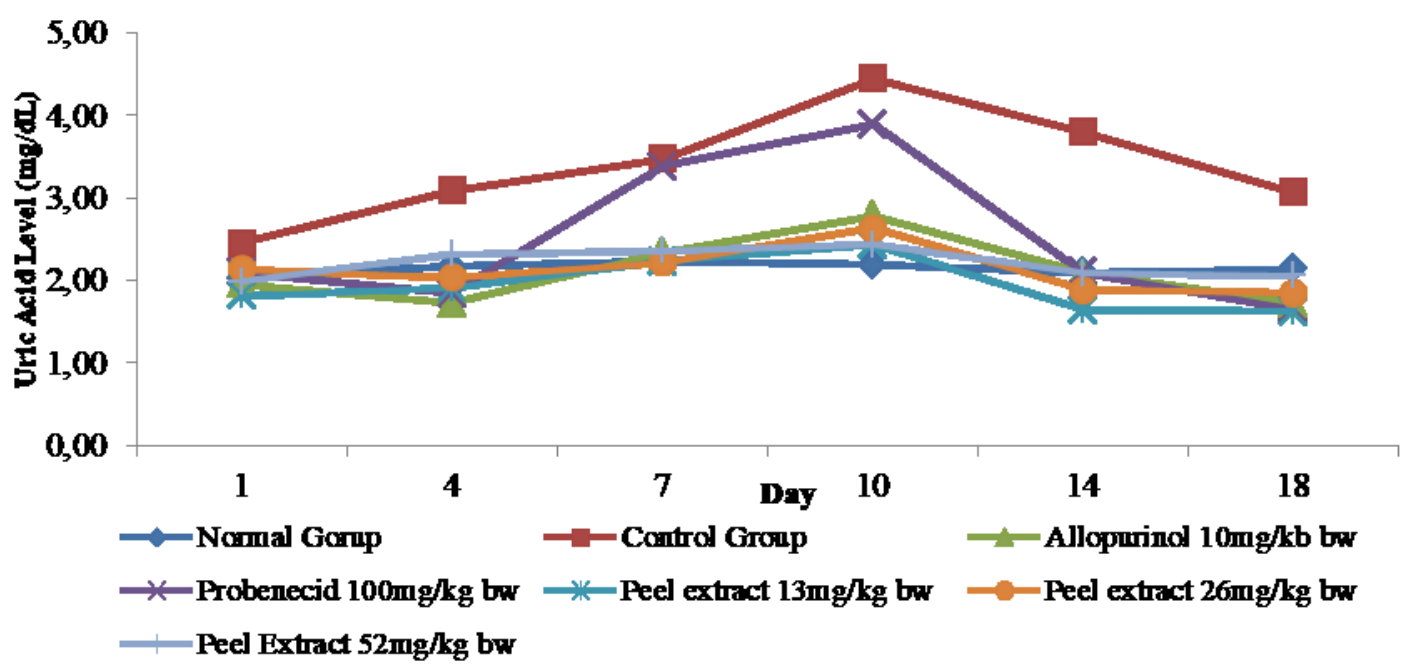

Figure 5 Graph of uric acid level with treatment of melinjo peel extract measured by a spectrophotometer uv-vis

The dose of melinjo peel extracts $26 \mathrm{mg} / \mathrm{kg}$ bodyweight can significantly reduce uric acid levels $(\mathrm{p}<0.05)$ for positive control group starting on day 3. Melinjo peel extract of $13 \mathrm{mg} /$ $\mathrm{kg}$ bodyweight and $52 \mathrm{mg} / \mathrm{kg}$ bodyweight significantly reduced uric acid levels $(\mathrm{p}<0.05)$ towards positive control group starting on day 4 . On the day 11 melinjo peel extract at a dose of 13,26 , and $52 \mathrm{mg} / \mathrm{kb}$ bodyweight showed a significant difference to allopurinol $(\mathrm{p}<0.05)$.

Peel of melinjo extract decreased uric acid level after reaching maximum increase (100\% hyperuricemia) until last day of treatment, at dose $13 \mathrm{mg} / \mathrm{kg}$ bodyweight equal to $31,25 \%$, at dose $26 \mathrm{mg} / \mathrm{kg}$ bodyweight equal to $30,03 \%$, and at dose of $52 \mathrm{mg} / \mathrm{kg}$ bodyweight equal to $15.63 \%$. Dose $13 \mathrm{mg} / \mathrm{kg}$ bodyweight peel extract of melinjo is the most effective dose to decreased uric acid level.

\section{Discussion}

A higher level of blood uric acid is called hyperuricemia and can cause the precipitation of uric acid in the joint, inducing pain and Gout arthritis. Hyperuricemia is a result of increased metabolism (overproduction) of uric acid, or reduction of secretion in the urine (under expression), or a combination of both. ${ }^{7}$ Consumption of food containing high purine will increase the risk of hyperuricemia. ${ }^{3}$

Allopurinol is the only drug approved for use in inhibiting uric acid synthesis through the inhibition of xanthine oxidase. ${ }^{8,9,10}$ The major side effects of allopurinol are skin rash, leukopenia, and occasional gastrointestinal toxicity. ${ }^{3,7}$ 


\section{Research Article}

Probenecid acts by inhibiting the reabsorption of uric acid in proximal tubules and consequently reduces the level of uric acid in the blood. ${ }^{7}$ Comparison with probenecid was used to evaluate the ability of extract the lower level uric acid reabsorption in the kidney that can be seen by the increase of uric acid level in the urine. ${ }^{7}$

The group with allopurinol did not reach peak of uric acid levels compared with positive control group. The group with probenecid reach peak of uric acid levels that approached the positive control group, because the probenecid comparison drug was only given on day 10. The group with allopurinol did not show a drastic increase in uric acid levels, but gradually decrease. In group with probenecid the decrease after induction was seen to be drastic. This is in line with the comparison of allopurinol as preventive and probenecid as curative. After reaching peak levels, in 4 days allopurinol reduced uric acid levels by $24.8 \%$, while probenecid $45.6 \%$.

Melinjo leaves and peel are known to contain flavonoids, which can reduce uric acid levels by inhibiting the action of the xanthine oxidase enzyme, so flavonoids are compounds that have the potential as antihyperuricemia. ${ }^{5,11,12}$ The inhibitory activity of xanthine oxidase from ethanol extract of melinjo rinds has been tested in vitro at $45.46 \%$ compared to the activity of allopurinol $27.28 \% .^{5}$

\section{Conclusion}

Ethanol extracts of melinjo (Gnetum gnemon L.) leaves and peel has the effect to decrease uric acid blood levels in hyperuricemia rats.

\section{References}

1. Baker JF, Schumacher HR. Update on gout and hyperuricemia. Int J Clin Pharm. 2010; 64(3): 371-7.

2. Lestari E, Maryanto S, Paundrianagari MD. Hubungan konsumsi makanan sumber purin dengan kadar asam urat pada wanita usia 45-59 tahun di Desa Sanggrahan Kecamatan Kranggan Kabupaten Temanggung. J Gizi Kes. 2015; 7(13).

3. Wahyuningsih S, Sukandar EY, Sigit, JI. Antihyperuricemia activity of ethanol extract of the calyx of Roselle (Hibiscus sabdariffa Linn.) on male Wistar rats. Proceedings, Asian Association of Schools of Pharmacy Conference $6^{\text {th }} .2013$.

4. Atun S. Pemanfaatan bahan alam bumi Indonesia menuju riset yang berkualitas internasional. Seminar Nasional Kimia UNY. 2010.

5. Wulandari S, Subandi, Muntholib. Inhibisi xantin oksidase oleh ekstrak etanol kulit melinjo (Gnetum gnemon) relatif terhadap allopurinol. J Onl Univ Neg Malang.2012;1(1):1-9.

6. Chow PKH, Ng RTH, Ogden BE, Using animal models in biomedical research. World Scientific Publishing; 2008.

7. Wahyuningsih S, Sukandar EY, Sukrasno, Lofika DN. Antihyperuricemia activity of the ethanol extract of Roselle Calyx and its fraction (Hibiscus sabdariffa Linn) on male Wistar rats. Int J Pharm Pharmaceut Sci. 2016;8(3).

8. Depkes RI. Pharmaceutical care untuk pasien penyakit arthritis rematik. Direktorat Bina Farmasi Komunitas dan Klinik; Ditjen Bina Kefarmasian dan Alat Kesehatan, Departemen Kesehatan; 2006.

9. Dipiro JT, Talbert RL, Yee GC, Matzke G, Weel B, Possey LM. Pharmacotherapy: a pathophysiologic approach. 7 th ed. NewYork, Mc Graw Hill; 2008. 


\section{Research Article}

10. Singh JA, Saag KG, Bridges SL, Bannuru RR, Sullivan MC. American College of Rheumatology Guideline for the treatment of Rheumatoid Arthritis, J Arthr Care Res. 2015; 68:1-26.

11. Depkes RI. Materia Medika Indonesia Jilid IV. Cetakan Pertama. Jakarta:Direktorat Jenderal Pengawasan Obat dan Makanan. 1980;94-8.

12. Barua CC, Haloi P. Gnetum gnemon Linn.: A comprehensive review on its biological, pharmacological and pharmacognostical potentials. Int J Pharmacog Phytochem Res. 2015;7(3);531-9. 